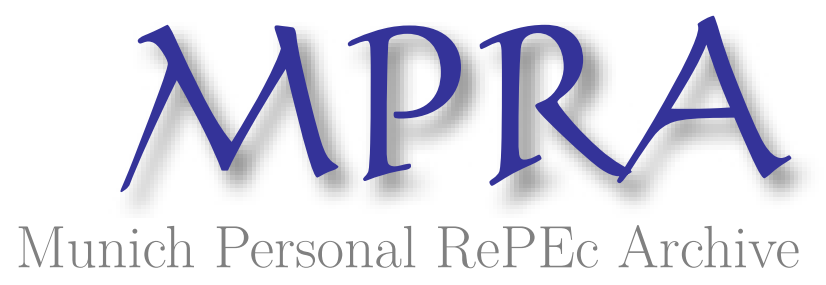

\title{
The Impacts of Farmland Expropriation on Vietnam's Rural Households
}

Le, Kien and Nguyen, My

2019

Online at https://mpra.ub.uni-muenchen.de/101397/

MPRA Paper No. 101397, posted 01 Jul 2020 09:47 UTC 


\title{
The Impacts of Farmland Expropriation on Vietnam's Rural Households
}

\author{
Kien Le \& My Nguyen ${ }^{\dagger}$
}

\begin{abstract}
The expropriation of agricultural land to provide new land for industrial and urban expansion, referred to as compulsory acquisition, is prevalent in developing countries. Using Vietnam as a laboratory, this study evaluates the impacts of losing farmland through compulsory acquisition on household welfare and reaches the following findings. A 10 percentage point increase in the proportion of land expropriated results in a $2.2 \%$ decrease in household welfare proxied by food expenditure. Besides, politically unconnected and ethnic minority households are disproportionately vulnerable. The adverse welfare effect could take up to 10 years to evaporate. The reduction in household welfare is attributable to the decline in agricultural income and the inability to participate in the non-agricultural labor market. Other aspects of household behavior following compulsory acquisition are also explored, such as saving, social capital, labor, and capital allocation.
\end{abstract}

JEL codes: O12, O13, R28, J22

Keywords: Land expropriation, rural households, Vietnam

$\dagger$ Contact: kle24@lsu.edu and mngu129@lsu.edu. Department of Economics, Louisiana State University. We thank the editor Dr. Hai-Anh Dang and two anonymous reviewers for insightful suggestions. We also thank participants at the 2019 Sustainability and Development Conference (Ann Arbor, MI) and the 2019 Vietnam's Business and Economics Research Conference (Ho Chi Minh City). Any errors remain our own. 


\section{Introduction}

Conversion of agricultural land into land designated for industrial and urbanized projects is an essential feature of industrialization in developing countries. The process has been facilitated by the power of government in which farmland is acquired without the consent of its owner or occupant, also referred to as compulsory acquisition (Keith et al., 2008). From a bird's eye view, compulsory acquisition is considered necessary when land must be devoted to growth-enhancing investments such as transportation networks and public facilities. However, for those whose farmland is expropriated, their traditional livelihoods are entirely uprooted, thus entailing significant costs of adjustment and resettlement. In spite of that, the compensations paid to them have been criticized as inadequate. Consequently, compulsory acquisition often fuels widespread social and political tensions, raising concerns among scholars, policymakers, and politicians. ${ }^{1}$

Despite the spate of media reports, there is still very little empirical evidence investigating the direct impacts of compulsory acquisition on rural households. Much of focus has been placed on the relationship between compulsory acquisition and urbanization at the aggregate level (see, for example, Narain (2009), Lin and Yi (2011), Xu et al. (2011), among others). Focusing on this under-explored area of research, this paper causally estimates the effects of compulsory acquisition on households' living standards and behaviors. By using household-level data within a regression framework, our work can be related to several studies such as Tran et al. (2014a, 2014b), Jiao et al. (2015) and Harris (2015). ${ }^{2}$ Since compulsory acquisition is often followed with social unrest and violence (Banerjee et al., 2007; Cao et al., 2008; Tang et al., 2008), carefully quantifying its impacts on affected households is crucial to facilitate a smoother and healthier structural transformation.

In this paper, we investigate the impacts of compulsory acquisition on rural households by considering the case of Vietnam. We aim to address how compulsory acquisition affects household welfare (proxied by food expenditure) and household resource allocation on

${ }^{1}$ For example, China reported a total of 17,900 cases of "massive rural incidents", in which a total of 385,000 farmers protested against the government during the first 9 months of 2006 (Cao et al., 2008).

2 Tran et al. (2014a, 2014b) find that compulsory acquisition has no effect on household income but leads to a declining share of agricultural income in Hoai Duc district (a peri-urban district of Vietnam). In the context of Cambodia, Jiao et al. (2015) report a reduction in household income if the household experiences land expropriation. Focusing on Ethiopia, Harris (2015) documents that expropriated households are no more likely to move into non-farm activities and experience falling share of income from crops. 
revenue-generating activities such as agricultural work, salaried employment, exploitation of common property resources, and self-employment. We also examine how households use their compensations from the government through their saving decisions.

We are interested in Vietnam because it is a country where the government relies heavily on compulsory land acquisition for industrial and urban expansion. For example, Anderson and Davidsen (2011) document that $10 \%$ of all agricultural land nationwide was expropriated between 2001 and 2010. More recently, a national priority on industrialization and modernization calls for the conversion of a large quantity agricultural land into industrial, export-processing, and hi-tech zones (World Bank, 2011; Adams, 2012; World Bank, 2012). With approximately $70 \%$ of the population living in rural area and $50 \%$ of the labor force working in agriculture, changing land use structure from agricultural to non-agricultural purposes carelessly by the Vietnamese government is reported to engender severe social consequences (Wells-Dang, 2013; Nguyen et al., 2014).

Our main contributions are as follows. First, we present empirical evidence on the causal effects of compulsory acquisition on rural household welfare. Second, we conduct heterogeneity analyses along the line of acquisition time, household political connection, and household ethnicity. Third, we provide rigorous analysis of household behaviors following compulsory acquisition, including resource allocation on various revenue-generating activities, social capital, and saving behaviors associated with cash compensations. Moreover, we differ from previous studies by further accounting for the intensive margin of the impacts of land acquisition (the fraction of the household's farmland being expropriated), instead of focusing only on the extensive margin of the effect (whether households are subject to compulsory acquisition).

Our identification strategy comes from within-household variations over time. By exploiting the panel nature of the Vietnam Access to Resources Household Survey, our paper reaches the following findings. First, compulsory acquisition depresses household welfare measured by food expenditure. Specifically, a 10 percentage point increase in the proportion of land expropriated leads to a decrease in household food expenditure by $2.2 \%$. Our analyses further suggest that the adverse consequences of compulsory acquisition may take up to 10 years to dissipate. Besides, politically unconnected and ethnic minority households are disproportionately vulnerable. Second, the reduction in household welfare can be attributed to a $9.0 \%$-decline in household agricultural income and household inability to get earnings 
from other sources. Third, we look at household detailed behavior following the acquisition. Expropriated households tend to reduce agricultural capital and labor after their land is taken away. Quantitatively, households divest their agricultural capital by $10.9 \%$ and reduce their working days in agriculture by $6.7 \%$ in response to a 10 percentage point increase in the proportion of farmland expropriated. While resources devoted to agriculture decrease, there is no evidence that households reallocate their resources to non-agricultural activities such as salaried jobs or self-employment. These results imply that the barrier to the non-agricultural labor market prevents expropriated households from shifting their labor supply away from agriculture. We also show that compulsory acquisition decreases household's contribution to agriculture-related social capital but not other forms of social capital. Furthermore, our findings indicate that cash compensations from the government increase household savings. By investigating the reasons for saving, we document a positive relationship between compensations and saving for educational purposes, with a suggestion that expropriated households attempt to raise their human capital, thus improving their competitiveness in the non-agricultural labor market.

From a normative perspective, rural households should not be made worse off due to compulsory acquisition. Moreover, they should be able to substitute the income generated from their expropriated farmland with earnings from other activities. However, none of these points is supported by our findings. Our results highlight the need for government interventions that go beyond a lump-sum payment. In particular, the government should adopt policies that aim to increase the competitiveness for non-agricultural occupations among the affected households. Our results also call for extra attention being directed towards the ethnic minority population who is disproportionately vulnerable and could fall further behind during the development process.

The paper proceeds as follows. The next Section 2 provides a brief discussion on the legal framework and related literature. Section 3 describes the data. In Section 4, we present our empirical strategy. Section 5 reports our results, heterogeneity analyses, and placebo tests. Section 6 concludes our paper. 


\section{Background and Literature Review}

\subsection{Legal Framework}

Dated by most authors, the period of central planning in Vietnam ended in 1986 with the introduction of various market-oriented reforms in both agricultural and non-agricultural sectors. In agriculture, a crucial reform was the enactment of Directive No.10 in 1988, which eliminated collective farming and regarded household as an independent unit of production in the economy. The Directive allowed agricultural land to be allocated to households along with certificates of land use rights (commonly known as Red Book). A Red Book is a license validating its recipient's rights to use an assigned parcel of land. ${ }^{3}$ With the issuance of the Directive, farmers were allowed to make their own decision regarding the uses of inputs and the sales of outputs, thus, fueling a substantial incentive for agricultural production. Later, another agricultural reform, the Law on Land 1993, was enacted granting farmers the right to trade their Red Books (i.e. transfer, exchange, lease, inheritance, and mortgage rights). Since then, a series of adjustments to the Law on Land was introduced in 1998, 2001, 2003, and 2008 to stimulate land market development.

It is important to note that agricultural land itself still belongs to the state. ${ }^{4}$ Farmers are only granted the right to use their state-assigned parcels for a certain amount of time. Formally, according to Article 1 and Article 5.1 of the Law on Land 2003, the land belongs to the entire people with the State as a representative of the ownership for the uniform administration of land. Article 5.2 and Article 22.1 further emphasize the powers of the State in land acquisition. According to these articles, the State shall exercise the right of land acquisition for purposes of socioeconomic development such as the development of industries, localities, and national security. Therefore, agricultural land can be expropriated when the land should be used for other public interests as rendered by the State. Article 42.2 further delineates the State's responsibility in paying compensations to those subject to compulsory land acquisition. The compensation amount is equal to the Red-Book value (based on cadastral surveys) at the time when the expropriation decision is made.

It is also interesting to understand how the process of compulsory acquisition works. First, a

${ }^{3}$ Information on a Red Book includes personal information of the recipient and plot characteristics (e.g. address, size, blueprint, expiration date, and land use purpose).

${ }^{4}$ Note also that farmers are granted the right to trade their land-use right, i.e. Red Book, not the land itself. 
5-year master land-use plan is established by the central government after being approved by the National Assembly. The master plan is designated to meet land demand based on the country's socioeconomic, defense, and security targets. According to the master plan, land is classified into three major groups, including (i) agricultural land such as rice land, forest land, and aquaculture land, (ii) non-agricultural land such as land for defense, land for industrial parks, and land for infrastructure development, and (iii) unused land such as land remaining unutilized and area to be used. After the aggregate targets are set for each land type (e.g. 1,578,000 hectares is designated for infrastructure development by 2020 (Resolution 17/2011/QH13)), the Ministry of Natural Resources and Environment and provincial governments work together to decide on the provincial, district, and commune targets for each land type. Since the process follows a top-down approach, the plan is highly rigid. Any adjustment at the lower administrative level requires changes in the aggregate targets set by the central government. Therefore, it is impossible for individual households to influence the master plan, which lays a foundation for our identifying assumption in Section 4, i.e. compulsory acquisition is not correlated with time-varying household characteristics.

As industrialization and urbanization become national priorities, a significant quantity of agricultural land has been acquired for urban-industrial expansion. For example, in 2006, the Vietnamese government issued Resolution 1107/QD-TTg expressing its determination to extend the total area of industrial zones at the expense of agricultural land. Quantitatively, almost 1 million hectares of agricultural land, which corresponds to $10 \%$ of the total agricultural land nationwide, were expropriated from 2001 to 2010 (Anderson and Davidsen, 2011). For a nation with $70 \%$ of the population living in rural areas where agricultural land is extensively used for daily livelihood (Wells-Dang, 2013), the acquisition of agricultural land often results in severe social consequences (Wells-Dang, 2013; Nguyen et al., 2014), thus, posing a challenge to both scholars and policy-makers.

\section{$2.2 \quad$ Literature Review}

Our paper is related to two strands of literature. The first strand of literature explores the effects of the compulsory acquisition on both macroeconomic and microeconomic outcomes. From the aggregate-level analyses, it is documented that land expropriation accelerates urbanization and transforms rural villages in developing countries (Narain, 2009; Lin and Yi, 2011; Xu et al., 2011). At the micro-level, a number of works concentrate on the interplay between the threat of acquisition and ex-ante investment in agricultural land. These papers 
find that farmers reduce investment in their farmland in response to the risk of compulsory acquisition. For example, Deininger and Jin (2006), Ali et al. (2011), and Fenske (2011) show that the threat of land expropriation reduces planting and productivity-enhancing practices in Africa. Jacoby et al. (2002) find that compulsory acquisition risk in China decreases the use of organic fertilizer but has no effect on other forms of plot-specific investment. In the context of India, Ghatak and Mookherjee (2014) documents that productivity-enhancing investments are also negatively influenced by compulsory acquisition.

Similar to ours, a few papers assess the economic and social consequences of the compulsory acquisition on the lives of expropriated households. Conducting household surveys in India, Ghatak et al. (2013) reveal that the acquisition of agricultural land leads to the reduction in income and loss of employment. Specifically, affected households still attempt to cultivate in non-acquired plots, and their agricultural income declines by $17 \%$. These results, however, are descriptive in nature, making it impossible to infer causality on the impacts of land acquisition. Others attempt to draw causal inferences from different identification strategies. Jiao et al. (2015) employ the propensity score matching method to investigate how compulsory acquisition affects rural households in Cambodia. The authors point out a reduction in household income by 15-19\% if the household experiences land expropriation. Nevertheless, the propensity score matching method cannot address the fact that there exist unobserved factors that influence both land acquisition and household income at the same time, thus, making it hard to interpret the estimated effects as causal. Our paper overcomes this endogeneity issue by exploiting the within-household variation over time in a household fixed effects model.

The closest works to our paper are Harris (2015) and Tran et al. (2014a, 2014b). Harris (2015) explores the effect of land acquisition in the context of Ethiopia on a group of individual farmers. Employing the first-difference method, Harris (2015) does not detect any effect on overall food consumption but finds that land-losing households substitute home-produced food with food purchased from the market. These households receive lower income share from crops and more from household business, while the share of earnings from other sources generally remains unchanged. Tran et al. (2014a, 2014b) employ the multinomial logit model to study the effects of land expropriation in the context of Vietnam. The authors detect the increase in consumption immediately following expropriation, a reduction in agricultural income share, and a transition from agricultural to informal-waged occupations. 
Both Harris (2015) and Tran et al. (2014a, 2014b) look at the impact of compulsory acquisition on income share from multiple sources. The use of income share does not correctly reflect the increase or decrease in each activity. For example, the increase in wages/salaries share could simply result from the reduction in agricultural earnings without the actual increase in earnings from wages/salaries. In this paper, we directly examine earnings (not the share) from various revenue-generating activities (e.g. agriculture, salaried jobs, self-employment). In this sense, our income measures are more meaningful and provide direct earnings comparison in each activity. Besides, Both Harris (2015) and Tran et al. (2014a, 2014b) tend to focus on the extensive margin, i.e. whether the farmer experiences land acquisition, instead of looking at the intensive margin, the proportion of land expropriated. Our paper makes use of the intensity of land acquisition, which could better capture the effects of interest since the impacts on households who had a larger share of farmland expropriated could potentially differ from the impacts on those who only lose a small proportion of farmland.

Our paper can further be distinguished from Tran et al. (2014a, 2014b) and Harris (2015) in multiple aspects. While Tran et al. (2014a, 2014b) only examine the immediate impacts of compulsory acquisition in a small peri-urban district (the effects of farmland lost 1-2 years ago), our study investigates the impacts of accumulated farmland expropriation (farmland was expropriated from many years ago up to a present year). Our estimation sample has a wider coverage with 134 districts of Vietnam over 8 years. Besides, we account for the potential endogeneity issue of land expropriation by adopting a household fixed effects model as well as conducting a series of placebo tests to support the causal interpretation of our findings. In this sense, our study complements Tran et al. (2014a, 2014b) by tackling the endogeneity issue and providing estimates that could be generalized to all Vietnamese rural households. ${ }^{5}$ Moreover, we differ from Harris (2015) and Tran et al. (2014a, 2014b) by further conducting rigorous analysis on (i) heterogeneity along the line of acquisition time, household political connection, household ethnicity, and (ii) household behaviors following land expropriation such as labor-capital allocation and behaviors contributing to social capital as well as savings.

Our work also fits into the second line of research which assesses the impacts of cash transfers in the context of developing countries. Previous works show that cash transfers from the government facilitate the transition of unemployed youths into formal employment (Blattman

\footnotetext{
5 Further comparison is provided in Appendix B.
} 
et al., 2013), raise household expenditure and investment in productive activities (Gertler et al., 2012). The context of our paper differs from that of the above-mentioned paper in the sense that households in our study receive cash payments after they lose one of their most crucial income-generating assets, agriculture land. Although compulsory acquisition and cash compensations are intimately connected, most studies, with the exception of Ghatak et al. (2013) and Harris (2015), tend to consider them individually. Addressing this gap, not only do we quantify the impacts of land acquisition, but we also explore how households use compensations after losing their land. Notably, we examine household saving behavior and various purposes of saving.

\section{Data}

To estimate the impacts of the compulsory acquisition on a wide range of household-level outcomes, we employ the Vietnam Access to Resources Household Survey (VARHS), carried out in even years from 2006 to 2014. The VARHS is part of the UNU-WIDER's project on "Structural transformation and inclusive growth in Vietnam". Conducted jointly with the Central Institute for Economic Management and the Vietnam Institute of Labour Science and Social Affairs, VARHS is an unbalanced panel survey of rural households in 12 provinces of Vietnam. ${ }^{6}$ It is worth noting that 2006-surveyed households were chosen to constitute a representative sample of the rural areas in the 12 provinces. However, the subsequent rounds $(2008,2010,2012$, and 2014) are not provincially representative in a strict statistical sense as they are based on the 2006-surveyed households.

The underlying sampling unit of VARHS is the household in rural Vietnam, which is composed of members living together and sharing income as well as expenditure for at least six months. Income and expenditure modules are defined consistently across the five waves of VARHS. For example, items underlying food expenditure and types of income-generating activities are all identical. The reference period is also the same, which always refers to the last 12 months for income and saving, and the monthly average for food expenditure as well as the number of workdays in various revenue-generating activities.

We group our outcomes of interest into four sets of variables. The first set includes household food expenditure and income from agricultural activities, common property resources, salaried

${ }^{6}$ The 12 provinces include Dak Lak, Dak Nong, Dien Bien, Ha Tay, Khanh Hoa, Lai Chau, Lam Dong, Lao Cai, Long An, Nghe An, Phu Tho, and Quang Nam 
jobs, as well as self-employment. Household food expenditure refers to the monthly total spending of all members on food. Household income from each activity refers to the income contribution of all household members from that activity. The second set consists of the current market value of total agricultural capital owned by the household, household time allocation on agricultural as well as non-agricultural work, and a dummy variable indicating whether the household has any member engaging in a salaried job. Household time allocation on an activity refers to the total number of workdays per month that all household members devote to that activity. Non-agricultural work covers all revenue-generating activities that are not classified as agriculture. The third set of outcomes includes social capital indicators such as whether the household has any member taking part in Farmer Union, Cooperative, and religious groups. The final set comprises household saving rate and dummy variables indicating various purposes of saving (e.g. for education, health care, old age, and interest-earning) in the last 12 months.

Summary statistics of the primary outcome and control variables are respectively presented in Table A1 in the Appendix. Mean values with standard deviations in the brackets are provided for the whole sample (Column 1) and disaggregated by land acquisition status (Columns 2 and 3). While food expenditure (in thousands VND) refers to the amount of money household spends on food per month, income (also in thousands VND) refer to the revenues household receives from various activities in the last 12 months. ${ }^{7}$ An average household spends approximately 547,000 VND on food consumption per month. Households whose lands are expropriated spend slightly more than those who do not lose their land.

The mean income from agriculture is around 9,968,000 VND annually, larger than the mean income from other activities, namely salaried jobs, common property resources, and self-employment. Households who experience compulsory acquisition tend to earn less from agriculture, common property resources, and self-employment but more from salaried employment, in comparison to non-expropriated households. Turning to time allocation, on average, households spend 22 days each month doing agricultural work, and 20 days doing non-agricultural work. The mean proportion of households with any member participating in salaried employment is 0.6 and the average value of agricultural capital is 1,160,000 VND.

Our main explanatory variable is the fraction of land expropriated. This variable is computed

\footnotetext{
7 Monetary values are adjusted for inflation and are expressed in the 2000 constant price.
} 
by dividing the household's accumulated area of expropriated land by the total land area in the survey period. The accumulated area of expropriated land refers to the total land area of the household being taken away up to the survey date. For example, the accumulated area of expropriated land reported in the 2010 survey includes all areas of the household's land taken away by the government in 2010 and before. Therefore, our measure of the fraction of land expropriated captures the cumulative effects of compulsory acquisition over time and not just the contemporaneous effects of expropriation. We refer to this measure as the Fraction of Land Expropriated hereafter. As reported in Table A1, the mean value of the Fraction of Land Expropriated is approximately $13 \%$ and $36 \%$ for all households and expropriated households, respectively. We also illustrate the distribution of Fraction of Land Expropriated among households who lose any part of their farmland in Figure A1. The horizontal axis gives the fraction of expropriated land while the vertical axis provides the frequency ranging from 0 to 1 .

The VARHS allows us to track the history of households' plots of farmland. Specifically, households were asked whether they had any plot expropriated, in which year the plot was taken, and the area of farmland lost through acquisition in each year. Figure 1 illustrates the fraction of land expropriated over time. In Panel (a), we provide the proportion of land lost through compulsory acquisition during each year (not accumulated). For example, sampled households lost less than $1 \%$ of their farmland in 2003. The share of land expropriated in 2011 was 2.5\%. Panel (b) demonstrates the accumulated share of expropriated land relative to the total area reported in the 2014 survey. For instance, the accumulated share of sampled households' land expropriated in 2003 was around 1.5\%, which also accounts for the land lost in 2003 and before.

\section{Empirical Methodology}

To investigate the relationships between compulsory acquisition and various outcomes at the household level, our estimating equation is given by,

$$
Y_{h t}=\beta_{0}+\beta_{1} F L E_{h t}+X_{h t}^{\prime} \Omega+\lambda_{h}+\delta_{t}+\epsilon_{h t}
$$

where $Y_{h t}$ denotes the outcomes of interest for household $h$ in year $t$. There are three sets of outcome variables. The first set contains monthly food expenditure, net annual income from agriculture, salaried jobs, common property resources, and self-employment (all in log 
Figure 1: Land Expropriation Over Time

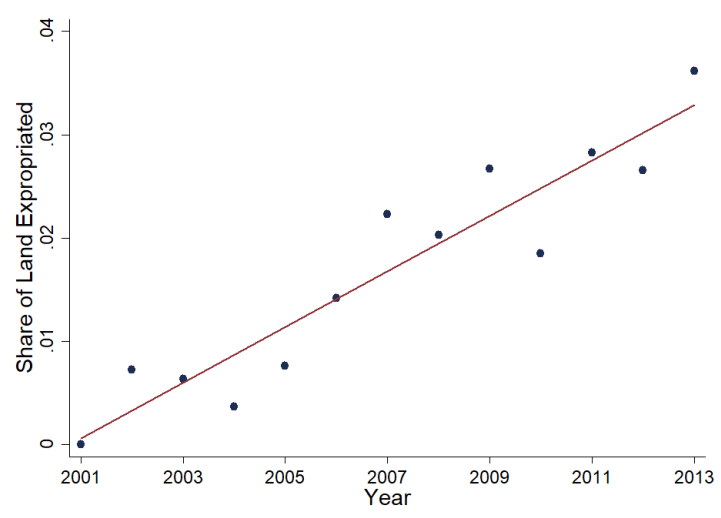

(a) Share of Land Expropriated by Year

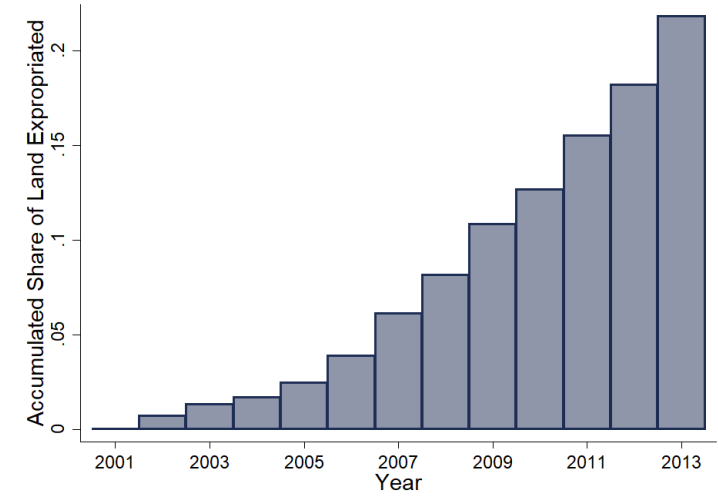

(b) Accumulated Share of Land Expropriated

Notes: Share of Land Expropriated refers to the proportion of the household land lost through acquisition during a given year. Accumulated Share of Land Expropriated refers to the proportion of the household land taken away up to a given year.

form). The second set consists of the log total market value of agricultural capital owned by the household, the log number of days spent on agricultural and non-agricultural work, and a dummy indicating salaried employment participation. The final set contains social capital indicators such as whether the household has any member taking part in Farmer Union, Cooperative, and religious groups.

Next, the term $F L E_{h t}$ represents our main explanatory variable, the Fraction of Land Expropriated, which is the fraction of household $h$ 's land that is cumulatively expropriated up to year $t$. The coefficient of interest is $\beta_{1}$, which reflects the causal effects of compulsory land acquisition on rural households in multiple aspects. Standard errors throughout the paper are clustered at the household level.

The vector $X_{h t}^{\prime}$ denotes other covariates including two groups. The first group includes household characteristics such as gender, age, age squared, ethnicity, and education of household head. ${ }^{8}$ The second group consists of household size (the number of members), household composition (proportion of young children and elderly disaggregated by gender), household total land area (in log), and whether any household member is affiliated with the Communist Party. A province-specific linear trend is also controlled for in the regression. The terms $\lambda_{h}$ and $\delta_{t}$ respectively represent household fixed effects and year fixed effects. We also denote by $\epsilon_{h t}$ an idiosyncratic and time-varying error term.

8 Education of the household head is an indicator that takes the value of 1 if the household head completes primary education and 0 otherwise. 
The inclusion of household fixed effects $\lambda_{h}$ is intended to eliminate confounding household's unobserved time-invariant characteristics that are correlated with the proportion of land expropriated and, at the same time, affects household outcomes. However, household fixed effects do not account for household unobserved time-varying characteristics that are correlated with the fraction of land subject to acquisition. The presence of such time-varying factors could potentially jeopardize our identification. For example, if households whose productivity tends to depreciate over time are more likely to have a higher fraction of land expropriated, then our coefficient estimate would be biased. We address this potential issue both qualitatively and quantitatively. Qualitatively, in Section 2.1, we provide a detailed discussion on the legal framework and designation of compulsory acquisition raising the plausibility of our identifying assumption, i.e. compulsory acquisition is not correlated with time-varying household characteristics. In particular, compulsory acquisition that converts agricultural land into land designated for urban and industrial purposes is planned by the Central State many years before compulsory acquisition actually occurs. The top-down approach of the acquisition process makes it impossible for any correlation between household unobserved time-varying characteristics and land expropriation to exist. In addition to providing qualitative discussion, we quantitatively perform two placebo tests in Section 5.5 to further strengthen our argument that the resulting estimates are indeed causal.

\section{Results}

\subsection{Compulsory Acquisition and Household Welfare}

We present the estimates of the effects of compulsory acquisition on household welfare proxied by household monthly food expenditure in Table 1. As evident in Column 1, losing their land through acquisition decreases household welfare. Specifically, a 10 percentage point increase in the fraction of land expropriated is associated with a $2.2 \%$ decline in household monthly spending on food.

In Column 2, instead of looking at the fraction of land expropriated, we examine the extensive margin (whether the household ever has their land taken away by the government). Exposure

to land expropriation reduces household food expenditure by $6.4 \%$. Since food consumption is a good measure of household welfare, especially in developing countries (Meyer and Sullivan, 2003; World Bank, 2014), our estimate implies that households are worse off when their farmland is expropriated. 
Table 1: Impacts of Compulsory Acquisition on Household Welfare

$\mathrm{Y}=$ Log Monthly Food Expenditure

(1)

(2)

(3)

Fraction of Land Expropriated $\quad-0.215^{* * *}$

Land Expropriation (Indicator)

$-0.064^{* *}$

Fraction of Land Expropriated $<4$ years ago

$-0.224^{* * *}$

Fraction of Land Expropriated 4-7 years ago

$-0.211^{* * *}$

Fraction of Land Expropriated 8-11 years ago

$-0.135$

Fraction of Land Expropriated $\geq 12$ years ago

0.321

$(0.227)$

Sample Size

9,381

9,381

9,381

Notes: Robust standard errors are clustered at household level. ${ }^{*} p<0.1,{ }^{* *} p<0.05,{ }^{* * *} p<0.01$. All Controls include (i) household characteristics such as gender, age, age squared, ethnicity, and education of household head, household size, demographic composition of household (proportion of young children and elderly disaggregated by gender), household total land area (in log), and whether any household member is affiliated with the Communist Party; (ii) household and year fixed effects, (iii) province-specific linear trend.

In order to distinguish between the long-run and the short-run effects of compulsory acquisition, we also estimate a modified version of our main specification (i.e. equation (1)) by replacing a single measure of the proportion of land lost through compulsory acquisition cumulatively up to a given year with four variables: (i) the fraction of land expropriated up to 4 years ago, (ii) the fraction of land expropriated from 4 to 7 years ago inclusively, (iii) the proportion of land expropriated from 8 to 11 years ago inclusively, and (iv) the proportion of land taken away 12 years ago and prior. It is worth noting that the sum of these four variables is equal to the Fraction of Land Expropriated in Column 1.

As shown in Column 3, there are negative repercussions on households in the short and medium run. These adverse consequences become less severe in the long run. Specifically, a 10 percentage point increase in the proportion of land expropriated up to 4 years ago and the fraction lost between 4 to 7 years ago are associated with the reduction in current food expenditure by $2.2 \%$ and $2.1 \%$, respectively. Interestingly, the fraction of land expropriated 
8-11 years ago or at least 12 years ago does not seem to have a significant impact on current household welfare. The results suggest that the adverse ramifications of compulsory acquisition on rural households' welfare may take up to 10 years to fade away.

\subsection{Heterogeneous Effects of Compulsory Acquisition}

In Vietnam, households without political connections and ethnic minority households tend to face many disadvantages. In particular, compared to those with strong ties to government officials, politically unconnected households in rural Vietnam have weaker property right protection and limited access to credit as well as transfer (Markussen and Tarp, 2014). Relative to the Kinh majority group, the ethnic minority population falls behind in multiple aspects, such as poorer living conditions, fewer employment opportunities, lower access to education, and other resources (World Bank, 2009; Dang, 2012). Therefore, it is of interest to analyze the heterogeneous impacts of compulsory acquisition on household welfare along the lines of political connection and ethnicity.

First, household political connection may be correlated with both household welfare and the proportion of expropriated land. Specifically, richer households with connection to local officials who are responsible for implementing the compulsory acquisition (Section 2.1), can reduce their area of expropriated farmland. Thus, besides conditioning on household affiliation with the Communist Party, we further control for a new variable proxying for household political connection (Relative/Friend with Officials). This variable is an indicator taking the value of 1 if household has any relative or friend holding office or trusted position in the commune, and 0 otherwise. The results are reported in Column 1 of Table 2. The magnitude is slightly reduced compared to the baseline estimate (Column 1, Table 1).

The pattern above suggests that the effects can be different between politically connected households and those without any political connection. Therefore, we estimate the effects of compulsory acquisition for each group separately in Columns 2 and 3 of Table 2. Politically unconnected households are those neither having friends/relative holding office/trusted position in the commune (Relative/Friend with Officials=0) nor having any household member affiliated with the Communist Party (Communist Party=0). Politically connected households are those either having friends/relative holding office/trusted position in the commune (Relative/Friend with Officials=1) or having any household member affiliated with the Communist Party (Communist Party=1). As expected, the effects of compulsory acquisition 
Table 2: Heterogeneous Impacts of Compulsory Acquisition on Household Welfare

\begin{tabular}{lccccc}
\hline & \multicolumn{5}{c}{ Y=Log Monthly Food Expenditure } \\
\cline { 2 - 6 } & All & Politically & Politically & Minority & Kinh \\
& Households & Unconnected & Connected & Ethnicity & Ethnicity \\
& & Households & Households & Households & Households \\
& $(1)$ & $(2)$ & $(3)$ & $(4)$ & $(5)$ \\
\hline Fraction of Land Expropriated & $-0.213^{* * *}$ & $-0.262^{* * *}$ & -0.109 & $-0.375^{* * *}$ & $-0.150^{* *}$ \\
& $(0.059)$ & $(0.073)$ & $(0.122)$ & $(0.133)$ & $(0.065)$ \\
Relative/Friend with Officials & $0.055^{*}$ & & $0.101^{*}$ & & \\
Communist Party & $(0.032)$ & & $(0.056)$ & & \\
& $0.060^{* * *}$ & & $0.099^{*}$ & & \\
Sample Size & $(0.017)$ & & $(0.052)$ & & 7,452 \\
\hline \hline
\end{tabular}

Notes: Robust standard errors are clustered at household level. ${ }^{*} p<0.1,{ }^{* *} p<0.05,{ }^{* * *} p<0.01$. All Controls include (i) household characteristics such as gender, age, age squared, ethnicity, and education of household head, household size, demographic composition of household (proportion of young children and elderly disaggregated by gender), household total land area (in log), and whether any household member is affiliated with the Communist Party; (ii) household and year fixed effects, (iii) province-specific linear trend.

are stronger for households without any political connection. For politically connected households, the estimate is statistically insignificant. Therefore, it is possible that the impacts of compulsory acquisition mainly come from politically unconnected households. Our findings are in line with Markussen and Tarp (2014) who document the relative advantage in terms of access to economic resources among Vietnamese households with political connections. In particular, the authors point out that having a relative as a government official raises the odd-ratios of receiving public transfers and obtaining credit by 1.43 and 1.62 , respectively.

Next, we provide the estimates of the impacts of compulsory acquisition on household welfare by household head's ethnicity in Columns 4 and 5 . There is a negative association between the fraction of land expropriated with household welfare for both minority households and Kinh (the major ethnicity) households. A 10 percentage point increase in the fraction of land expropriated is associated with the reduction in monthly food expenditure by approximately $3.8 \%$ and $1.5 \%$ for minority and Kinh households, respectively. The magnitude of the impacts is much larger for minority households. This observation raises a critical concern that compulsory acquisition during urbanization and industrialization could perpetuate the ethnic inequality in Vietnam. For instance, Dang (2012) shows that the poverty rate among ethnic minority people is five times higher than that of the majority Kinh and the educational gap between these groups is almost 2.5 years. The author also points out that minority people 
have lower access to health care and higher child mortality rate. Given these enormous disparities, we urge the Vietnam government to pay extra attention to minorities to save this group from falling even further behind during the development process.

\subsection{Compulsory Acquisition and Household Income}

Next, to explain the fall in food expenditure, we examine the effects of compulsory acquisition on household income from various activities. The results in Table 3 indicate that the loss of land through compulsory acquisition lowers household earnings from agriculture but not from other activities. A 10 percentage point increase in the proportion of land expropriated leads to a $9 \%$ decrease in agricultural income (Column 1). Since land is the key input to agricultural production, the loss of farmland unsurprisingly depresses farm output and reduces household income from agriculture. This finding is consonant with Ghatak et al. (2013) and Jiao et al. (2015) who also detect a decline in agricultural earnings following land acquisition.

Turning to non-agricultural income, we find that land-losing households are unable to substitute the loss in agricultural income with income from non-agricultural activities. Particularly, compulsory acquisition does not have any impact on household income from salaries as the coefficient estimate is positive but falls short of statistical significance (Column 2). The effects of compulsory acquisition on household income from common property resources and self-employment are all negative but statistically indistinguishable from zero (Columns 3 and 4). If we instead look at the share of income from each source in household total income, we uncover similar findings to Tran et al. (2014b). Specifically, the fraction of land expropriated is negatively associated with the share of agricultural income but positively associated with the share of income from wages/salaries (Table A2).

Overall, compulsory acquisition results in the loss of income and employment opportunities for rural households. Income loss accounts for the reduction in household welfare as evidenced by the drop in food expenditure. Given that approximately half of total employment in Vietnam comes from agriculture, rural households are especially vulnerable to land acquisition. If they cannot substitute agricultural income loss arising from compulsory acquisition with alternative forms of income, rural households could become marginalized during the period of urban-industrial expansion, worsening the income inequality problem in Vietnam. 
Table 3: Impacts of Compulsory Acquisition on Household Income

\begin{tabular}{lcccc}
\hline & $\begin{array}{c}\text { Log Income } \\
\text { from } \\
\text { Agriculture } \\
(1)\end{array}$ & $\begin{array}{c}\text { Log Income } \\
\text { from } \\
\text { Salaried Jobs } \\
(2)\end{array}$ & $\begin{array}{c}\text { Log Income } \\
\text { from Common } \\
\text { Property Resource }\end{array}$ & $\begin{array}{c}\text { Log Income } \\
\text { from }\end{array}$ \\
$\begin{array}{lcccl}\text { Self Employment } \\
(4)\end{array}$ & $(4)$ \\
\hline Fraction of Land Expropriated & $-0.903^{* * *}$ & 0.124 & -0.257 & -0.053 \\
& $(0.110)$ & $(0.119)$ & $(0.208)$ & $(0.191)$ \\
Sample Size & 8,462 & 5,673 & 2,930 & 2,530 \\
\hline \hline
\end{tabular}

Notes: Robust standard errors are clustered at household level. ${ }^{*} p<0.1,{ }^{* *} p<0.05,{ }^{* * *} p<0.01$. All Controls include (i) household characteristics such as gender, age, age squared, ethnicity, and education of household head, household size, demographic composition of household (proportion of young children and elderly disaggregated by gender), household total land area (in log), and whether any household member is affiliated with the Communist Party; (ii) household and year fixed effects, (iii) province-specific linear trend.

\subsection{Household Behaviors Following Compulsory Acquisition}

In this section, we explore in details the four main aspects of household behaviors following compulsory acquisition, including (i) household allocation of agricultural production factors, i.e. capital and labor, (ii) household entry to other non-agricultural occupations, (iii) changes in household behaviors that contribute to social capital, and (iv) household saving behaviors.

Capital and Labor Allocation - First, we expect households to decrease the amount of both capital and labor devoted to agricultural activity after their land is seized. This is exactly what we find in Table 4. We estimate equation (1) with the outcome variables being the log of household's total market value of agricultural capital (Column 1) and the log of the monthly-average number of days household spends on agricultural activity (Column 2). The estimated effects on agricultural capital and labor are negative and statistically distinct from zero. Specifically, the value of agricultural capital falls by $10.9 \%$ in response to a 10 percentage point increase in the fraction of expropriated land. Intuitively, once households lose part of their farmland, they may not need as much agricultural equipment as before and could divest some of their agricultural capital. Analogously, households also devote less time to agricultural work. An additional 10 percentage point increase in the fraction of expropriated land is associated with the reduction in the monthly average number of days spent on farming by $6.7 \%$.

Second, although households spend less time on agricultural activities and reduce agricultural capital, they are no more likely to switch to other non-agricultural work. Formally, we estimate equation (1) with the outcome variables being the log of the monthly-average number of days 
Table 4: Impacts of Compulsory Acquisition on Capital and Labor Allocation

\begin{tabular}{ccccc}
\hline & $\begin{array}{c}\text { Log Value of } \\
\text { Agricultural Capital } \\
(1)\end{array}$ & $\begin{array}{c}\text { Log Days Spent } \\
\text { in Agriculture } \\
(2)\end{array}$ & $\begin{array}{c}\text { Log Days Spent } \\
\text { in Non-Agriculture } \\
(3)\end{array}$ & $\begin{array}{c}\text { Having a } \\
\text { Salaried Job } \\
(4)\end{array}$ \\
\hline Fraction of Land & $-1.089^{* * *}$ & $-0.667^{* * *}$ & 0.108 & 0.009 \\
Expropriated & $(0.228)$ & $(0.077)$ & $(0.131)$ & $(0.038)$ \\
Sample Size & 9,381 & 9,381 & 9,381 & 9,381 \\
\hline \hline
\end{tabular}

Notes: Robust standard errors are clustered at household level. ${ }^{*} p<0.1,{ }^{* *} p<0.05,{ }^{* * *} p<0.01$. All Controls include (i) household characteristics such as gender, age, age squared, ethnicity, and education of household head, household size, demographic composition of household (proportion of young children and elderly disaggregated by gender), household total land area (in log), and whether any household member is affiliated with the Communist Party; (ii) household and year fixed effects, (iii) province-specific linear trend.

household spends on non-agricultural activities (Column 3) and an indicator that takes a value of 1 if any household member participates in salaried employment and 0 otherwise (Column 4). Despite being positive, these estimates are statistically and economically insignificant, suggesting that compulsory acquisition does not have any effect on the number of days spent on non-agricultural activities nor on the probability of participating in salaried employment. Taken together, Table 4 provides evidence that while land-losing households divest their agricultural capital and reduce their working time in agriculture, they cannot transition into non-agricultural occupations. Our estimates in Table 4 offer a deeper explanation for the conclusion of Section 5.3, i.e. household's inability to replace agricultural income loss with alternative forms of income. In particular, households are unable to supply their labor in the non-agricultural labor market.

Social Capital - Given the importance of social capital in a broad range of outcomes such as household welfare (Yusuf, 2008; Adepoju and Oni, 2012), credit access (Grootaert et al., 2002), and micro-enterprise performance (Santarelli and Tran, 2013), it is also of interest to examine potential changes in household behaviors that contribute to social capital. To do so, we estimate equation (1) with a set of dummy variables indicating household's contribution to social capital as dependent variables.

The results are reported in Table 5. The dependent variables include a dummy that takes the value of 1 if any household member is part of the Farmer Union and 0 otherwise (Column 1); an indicator that equals 1 if any household member is part of a Cooperative and 0 otherwise (Column 2); and an indicator that takes a value of 1 if any household member is affiliated 
Table 5: Impacts of Compulsory Acquisition on Social Capital

\begin{tabular}{cccc}
\hline & $\begin{array}{c}\text { Being a Member of } \\
\text { Farmer Union } \\
(1)\end{array}$ & $\begin{array}{c}\text { Being a Member of } \\
\text { Cooperative } \\
(2)\end{array}$ & $\begin{array}{c}\text { Being a Member of } \\
\text { religious group } \\
(3)\end{array}$ \\
\hline Fraction of Land & $-0.068^{*}$ & -0.005 & 0.000 \\
(Expropriated) & $(0.041)$ & $(0.009)$ & $(0.028)$ \\
Sample Size & 9,360 & 9,360 & 9,360 \\
\hline \hline
\end{tabular}

Notes: Robust standard errors are clustered at household level. ${ }^{*} p<0.1,{ }^{* *} p<0.05,{ }^{* * *} p<0.01$. All Controls include (i) household characteristics such as gender, age, age squared, ethnicity, and education of household head, household size, demographic composition of household (proportion of young children and elderly disaggregated by gender), household total land area (in log), and whether any household member is affiliated with the Communist Party; (ii) household and year fixed effects, (iii) province-specific linear trend.

with a religious group and 0 otherwise (Column 3). We find that a higher fraction of land expropriated decreases the probability of household being a member of the Farmer Union. A 10 percentage point increase in the fraction of land expropriated decreases the likelihood of households being affiliated with the Farmer Union by approximately 0.68 percentage points. Compulsory acquisition, however, does not have any effect on household membership with a Cooperative or a religious group. Quantitatively, the resulting estimates presented in Columns 2 and 3 are economically and statistically insignificant. According to this exercise, the main takeaway is that compulsory acquisition reduces household's contribution to agriculture-related social capital, not the other forms of social capital.

Saving Behaviors - Finally, we investigate how compulsory acquisition can alter household saving behaviors. As discussed in Section 2.1, after the seizure of land, cash payments from the state are provided to affected households to compensate for their loss of farmland. Cash transfers have been shown by previous studies to improve the livelihoods of the disadvantaged group in developing countries by increasing employment opportunities and consumption (Blattman et al., 2013; Gertler et al., 2012). In our context, household could use the compensations to purchase new plots of land and continue working in agriculture or to use compensations for other non-agricultural purposes. The reduction in agricultural income induced by the declines in both capital and labor devoted to agriculture documented in the last section suggestively negates the former possibility.

In this section, we further explore how households make use of cash compensations following compulsory acquisition. To do so, we re-estimate equation (1) with the compensation amount household received (in $\log$ form) being the main explanatory variable, instead of the fraction 
Table 6: Impacts of Cash Compensations on Saving Behaviors

\begin{tabular}{lccccc}
\hline & $\begin{array}{c}\text { Household } \\
\text { Saving Rate } \\
(1)\end{array}$ & $\begin{array}{c}\text { Saving for } \\
\text { Education } \\
(2)\end{array}$ & $\begin{array}{c}\text { Saving for } \\
\text { Health Care } \\
(3)\end{array}$ & $\begin{array}{c}\text { Saving for } \\
\text { Old Age } \\
(4)\end{array}$ & $\begin{array}{c}\text { Saving to } \\
\text { Earn Interests } \\
(5)\end{array}$ \\
\hline $\begin{array}{c}\text { Log Compensation } \\
\text { Amount }\end{array}$ & $0.110^{*}$ & $0.021^{* *}$ & 0.005 & -0.001 & 0.010 \\
Sample Size & $(0.065)$ & $(0.010)$ & $(0.004)$ & $(0.021)$ & $(0.006)$ \\
\hline \hline
\end{tabular}

Notes: Robust standard errors are clustered at household level. ${ }^{*} p<0.1,{ }^{* *} p<0.05,{ }^{* * *} p<0.01$. All Controls include (i) household characteristics such as gender, age, age squared, ethnicity, and education of household head, household size, demographic composition of household (proportion of young children and elderly disaggregated by gender), household total land area (in log), and whether any household member is affiliated with the Communist Party; (ii) household and year fixed effects, (iii) province-specific linear trend.

of land expropriated $\left(F L E_{h t}\right)$. Here, the dependent variables of interest include household saving rate and indicators for various purposes of saving. Household saving rate is computed by dividing the household total savings by household total net income. There are four saving-purpose indicators: Saving for Education (Column 2) takes the value of 1 if household wants to save for educational purposes and 0 otherwise, Saving for Health Care (Column 3) takes the value of 1 if household savings are intended for medical expenditure and 0 otherwise, Saving for Old Age (Column 4) takes the value of 1 if household wants to save for their retirement funds and 0 otherwise, Saving to Earn Interests (Column 5) takes the value of 1 if household savings are put in the bank to earn interest and 0 otherwise.

The estimating results are reported in Table 6. We find that the compensation amount is positively associated with household saving rate (Column 1). In other words, the higher the compensations, the more household tend to save. Moving to purposes of savings (Columns 2 through 5), a higher compensation amount leads to an increase in the probability of saving for education but not for other purposes such as health care, old age, and interest earning. Taken together, we find evidence that households attempt to raise their stock of human capital. Suggestively, it could be the case that households intend to raise their competitiveness in the non-agricultural labor market by investing in human capital.

\subsection{Placebo Tests}

As we discussed in Section 4, the inclusion of household fixed effects cannot eliminate household time-varying characteristics that are correlated with the fraction of land expropriated. While the top-down approach in designating land acquisition makes it almost impossible for land 
expropriation to be correlated with household characteristics (see Section 2.1), we further strengthen this argument by conducting additional quantitative analysis. In particular, we perform two placebo tests supporting the causal interpretation of our estimated effects of compulsory acquisition on food expenditure and agricultural income.

In the first placebo test, we estimate the effects of compulsory acquisition on household welfare (proxied by food expenditure) before their land is actually expropriated. To do so, we simply regress the outcomes of interest on the land expropriation indicator (taking the value of 1 if household ever loses any part of their land through compulsory acquisition, 0 otherwise). It is important to emphasize that this is not panel regression i.e., household fixed effects are not included. The unit of observation in this exercise is a unique household; therefore, the sample size is reduced substantially.

It is also worth noting that we cannot do this placebo test for the effects of treatment intensity, i.e. regressing on $F L E_{h t}$, as the fraction of land expropriated changes over time. The motivation for this placebo test is as follows. If household's unobserved characteristics are uncorrelated with the probability of expropriation, there should be no relationship between household outcomes prior to land acquisition and household's expropriation status. In other words, if compulsory acquisition indeed has negative impacts on food expenditure, we expect the placebo estimates to be statistically insignificant.

The results are provided in Table 7 . Column 1 presents the actual estimate of the effects of compulsory acquisition on food expenditure (the same as Column 2, Table 1). In Column 2, Land Expropriation (Indicator) takes the value of 1 if households did not experience compulsory acquisition in 2006 but had their farmland expropriated in subsequent years, 0 otherwise. ${ }^{9}$ Expropriated households in 2006 are dropped because we do not observe characteristics prior to 2006. The coefficient on Land Expropriation (Indicator) captures the "impact" of compulsory acquisition (occurring after 2006) on household welfare in 2006. The placebo estimate has an opposite (wrong) sign and is statistically indistinguishable from zero. In Column 3, Land Expropriation (Indicator) takes the value of 1 if households did not experience compulsory acquisition in 2006 and 2008 but were subject to such event in subsequent years, 0 otherwise (expropriated households during 2006-2008 are excluded).

\footnotetext{
${ }^{9}$ In the first placebo test, Land Expropriation (Indicator) takes the value of 1 if household did not experience compulsory acquisition in a given year but were subject to such event in subsequent years, 0 otherwise. Therefore, the sample size is smaller than that in the baseline regression in Column 1.
} 
Table 7: Placebo Tests

\begin{tabular}{lcccccc}
\hline & \multicolumn{4}{c}{$Y=$ Log Monthly Food Expenditure } \\
\cline { 2 - 3 } \cline { 5 - 7 } & \multicolumn{2}{c}{ Actual Estimate } & \multicolumn{4}{c}{ Placebo Estimates } \\
\cline { 2 - 3 } \cline { 5 - 7 } & $(1)$ & & $(2)$ & $(3)$ & $(4)$ & $(5)$ \\
\hline Land Expropriation (Indicator) & $-0.064^{* *}$ & & 0.043 & -0.014 & 0.023 & -0.002 \\
& $(0.027)$ & & $(0.043)$ & $(0.046)$ & $(0.050)$ & $(0.063)$ \\
Sample Size & 9,381 & & 1,502 & 1,370 & 1,220 & 1,081 \\
\hline \hline
\end{tabular}

Notes: Robust standard errors are clustered at household level. ${ }^{*} p<0.1,{ }^{* *} p<0.05,{ }^{* * *} p<0.01$. Controls include (i) household characteristics such as gender, age, age squared, ethnicity, and education of household head,, household size, demographic composition of household (proportion of young children and elderly disaggregated by gender), household total land area (in $\log$ ), and whether any household member is affiliated with the Communist Party; (ii) year fixed effects, (iii) province-specific linear trend. Household fixed effects are only included in the Column 1.

Similarly, in Column 4, Land Expropriation (Indicator) takes the value of 1 if households did not experience compulsory acquisition from 2006 to 2010 but had their farmland expropriated in subsequent years, 0 otherwise (households subject to acquisition during 2006-2010 are dropped). In Column 5, Land Expropriation (Indicator) takes the value of 1 if the household did not experience compulsory acquisition from 2006 to 2012 but was subject to such event in subsequent years, 0 otherwise (households exposed to acquisition during 2006-2012 are omitted). The placebo estimates are both economically and statistically insignificant, supporting the causal interpretation of the actual estimate.

In the second placebo test, we randomly assign the treatment status of having land expropriated to households, with the assigned years drawn from the actual pool of treatment years, without replacement. Put it differently, in a given year, the number of households being randomly assigned to have the placebo land expropriation is the same as the actual number of households. Besides, conditional probability (assigning without replacement) ensures that the treatment status of a placebo expropriated household does not change once being assigned. We do this for 1,000 sets of placebo compulsory acquisition and estimate equation (1). Figure 2 plots the distribution of point estimates for food expenditure. The vertical red line denotes the actual estimate. The location of the true estimate indicates that the likelihood of finding the effect of interest merely by chance is very unlikely. Taken together, the results from two placebo tests suggest that our estimated effects of compulsory acquisition could be interpreted as causal. 
Figure 2: Compulsory Acquisition and Household Welfare - Placebo Estimates

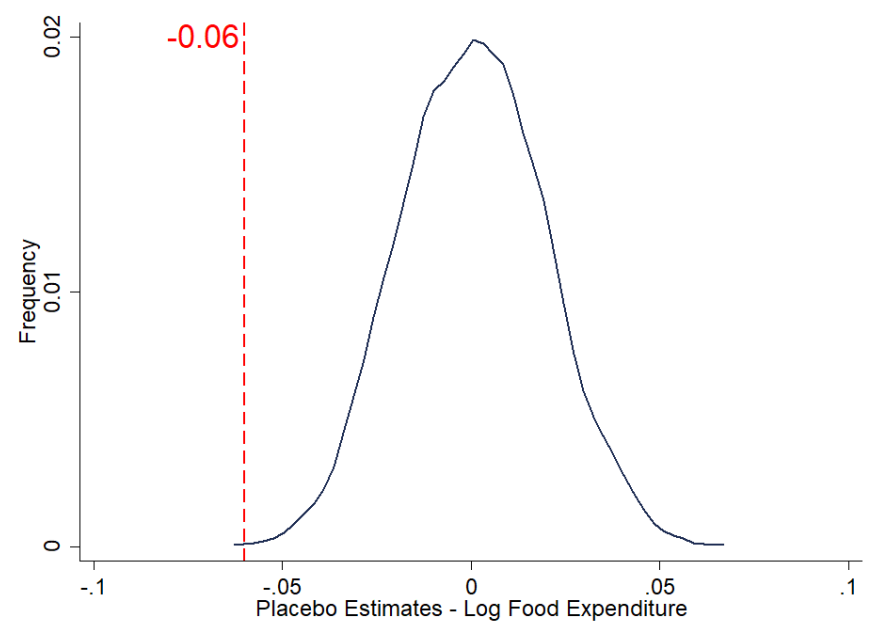

\section{Conclusion}

Exploiting the panel nature of the Vietnam Access to Resources Household Survey which provides rich information on rural households within a fixed effect regression framework, we uncover the negative impacts of compulsory acquisition on household welfare (proxied by food expenditure). Specifically, a 10 percentage point increase in the fraction of land expropriated results in a $2.2 \%$ reduction in food expenditure. Our analyses further suggest that the adverse consequences of compulsory acquisition on household welfare may take up to 10 years to evaporate. Besides, politically unconnected and ethnic minority households are disproportionately vulnerable. We attribute the decline in household welfare to the $9 \%$ decrease in agricultural income and household's inability to participate in non-agricultural activities. A deeper analysis shows that the barrier to the non-agricultural labor market prevents expropriated households from shifting their labor supply away from agriculture. We also find that compulsory acquisition decreases household's contribution to agriculture-related social capital but not other forms of social capital. In the analysis of household saving, we provide evidence that cash compensations increase household saving rate. A closer look at the saving purposes reveals that households intend to raise their human capital levels, thus, their competitiveness in the non-agricultural labor market.

The presented findings offer meaningful implications for policy-making on structural transformation and urbanization. In the process of rapid industrialization and urbanization, compulsory acquisition is an inevitable phenomenon in many developing countries, forcing millions of people off their farm livelihood (Xu et al., 2011; Jiao et al., 2015). The practice of 
compulsory acquisition is particularly prevalent in Vietnam, as it is one of the fastest-growing economies. Hence, by using Vietnam as a laboratory, our study reveals that the loss of farmland due to compulsory acquisition lowers household welfare because households lose earnings from agriculture but cannot switch to other non-agricultural occupations. The provision of cash compensations alone does not solve the problem. Our findings call for immediate action by the policy-makers to ensure the lives of land-losing households. Government interventions should aim to facilitate household participation in the non-agricultural labor market such as enhancing skills and competitiveness for expropriated households. Extra attention should be paid to the ethnic minority population who are disproportionately vulnerable and could fall further behind during the development process. 


\section{References}

[1] Adam, C. (2012). Land Reform, Livelihoods and Poverty in Vietnam. Background paper prepared for Oxfam in Vietnam, September.

[2] Adepoju, A. A., and Oni, O. A. (2012). Investigating Endogeneity Effects of Social Capital on Household Welfare in Nigeria: A Control Function Approach. Quarterly Journal of International Agriculture, 51(892-2016-65161), 73.

[3] Ali, D. A., Dercon, S., and Gautam, M. (2011). Property Rights in a Very Poor Country: Tenure Insecurity and Investment in Ethiopia. Agricultural Economics, 42(1):7586.

[4] Anderson, J., and Davidsen, S. (2011). Recognizing and Reducing Corruption Risks in Land Management in Viet Nam. Hanoi: National Political Publishing House (Su That).

[5] Anderson, James; Jaffee, Steven M.; Pham, Hoa Thi Mong; Soucat, Agnes L. B.; Nguyen, Dzung Huy; Tran, Huong Thi Lan. (2012). Revising the Land Law to Enable Sustainable Development in Vietnam : Summary of Priority Policy Recommendations Drawn from World Bank studies. Washington DC : World Bank.

[6] Banerjee, A. V., Bardhan, P., Basu, K., Chaudhury, M. D., Ghatak, M., Guha, A. S., Majumdar, M., Mookherjee, D., and Ray, D. (2007). Beyond Nandigram: Industrialisation in West Bengal. Economic and Political Weekly, 1487-1489.

[7] Blattman, C., Fiala, N., and Martinez, S. (2013). Generating Skilled Self-employment in Developing Countries: Experimental Evidence from Uganda. The Quarterly Journal of Economics, 129(2), 697-752.

[8] Cao, G., Feng, C., and Tao, R. (2008). Local Land Finance in China's Urban Expansion: Challenges and Solutions. China and World Economy, 16(2), 19-30.

[9] Dang, H. (2012). Vietnam. In G. Hall and H. Patrinos (Eds.), Indigenous Peoples, Poverty, and Development (pp. 304-343). Cambridge: Cambridge University Press.

[10] Deininger, K., and Jin, S. (2006). Tenure Security and Land-Related Investment: Evidence from Ethiopia. European Economic Review, 50(5), 1245-1277.

[11] Fenske, J. (2011). Land Tenure and Investment Incentives: Evidence from West Africa. Journal of Development Economics, 95(2), 137-156.

[12] Gertler, P. J., Martinez, S. W., and Rubio-Codina, M. (2012). Investing Cash Transfers to Raise Long-term Living Standards. American Economic Journal: Applied Economics, 4(1), 164192.

[13] Ghatak, M., and Mookherjee, D. (2014). Land Acquisition for Industrialization and Compensation of Displaced Farmers. Journal of Development Economics, 110, 303-312. 
[14] Ghatak, M., Mitra, S., Mookherjee, D., and Nath, A. (2013). Land Acquisition and Compensation: What Really Happened in Singur?. Economic and Political Weekly, $32-44$.

[15] Grootaert, C., Oh, G. T., and Swamy, A. (2002). Social Capital, Household Welfare and Poverty in Burkina Faso. Journal of African Economies, 11(1), 4-38.

[16] Guha, A. M. A. (2008). A Decade After Land Acquisition in Paschim Medinipur, West Bengal. Journal of the Indian Anthropological Society, 43, 121-133.

[17] Harris, A. (2015). Expropriation, Compensation and Transitions to New Livelihoods: Evidence from an Expropriation in Ethiopia. Economics Series Working Paper WPS/201504. Oxford: University of Oxford, Department of Economics.

[18] Jacoby, H. G., Li, G., and Rozelle, S. (2002). Hazards of Expropriation: Tenure Insecurity and Investment in Rural China. American Economic Review, 92(5), 1420-1447.

[19] Jiao, X., Smith-Hall, C., and Theilade, I. (2015). Rural Household Incomes and Land Grabbing in Cambodia. Land Use Policy, 48, 317-328.

[20] Keith, S., McAuslan, P., Knight, R., Lindsay, J., Munro-Faure, P., Palmer, D., and Spannenberg, L. (2008). Compulsory Acquisition of Land and Compensation. FAO Land Tenure Studies, 10.

[21] Law on Land (2003). Law on Land No. 13-2003-QH11 dated 25 December 2001.

[22] Lin, G. C., and Yi, F. (2011). Urbanization of Capital or Capitalization on Urban Land? Land Development and Local Public Finance in Urbanizing China. Urban Geography, 32(1), 50-79.

[23] Markussen, T., and Tarp, F. (2014). Political Connections and Land-related Investment in Rural Vietnam. Journal of Development Economics, 110, 291-302.

[24] Meyer, B. D., and Sullivan, J. X. (2003). Measuring the Well-being of the Poor Using Income and Consumption. The Journal of Human Resources, 38, 1180-1220.

[25] Narain, V. (2009). Growing City, Shrinking Hinterland: Land Acquisition, Transition and Conflict in Peri-urban Gurgaon, India. Environment and Urbanization, 21(2), 501-512.

[26] Phuc, N. Q., Van Westen, A. C. M., and Zoomers, A. (2014). Agricultural Land for Urban Development: The Process of Land Conversion in Central Vietnam. Habitat International, 41, 1-7.

[27] Resolution 1107/QD-TTg (2006). On Approving the Planning on Development of Industrial Parks in Vietnam up to 2015 and Orientations to 2020. Available in English at: https://luatminhkhue.vn/en/decision/decision-no-1107-qd-ttg-dated-august-212006-of-the-prime-minister-approving-the-planning-on-development-of-industrial-parksin-vietnam-up-to-2015-and-orientations-to-2020.aspx 
[28] Resolution 17/2011/QH13 (2011). On the Land Use Mater Plan up to 2020 and National Five-year (2011-2015) Land Use Plan. Available in Vietnamese and English at: www.mpi.gov.vn/Pages/tinbai.aspx?idTin=20565. www.vietnamredd.org/Upload/CMS/Content/Library-GovernmentDocuments/17 2011 QH13.pdf

[29] Santarelli, E., and Tran, H. T. (2013). The Interplay of Human and Social Capital in Shaping Entrepreneurial Performance: the Case of Vietnam. Small Business Economics, 40(2), 435-458.

[30] Tang, B. S., Wong, S. W., and Lau, M. C. H. (2008). Social Impact Assessment and Public Participation in China: A Case Study of Land Requisition in Guangzhou. Environmental Impact Assessment Review, 28(1), 57-72.

[31] Tran, Q. T., Lim, S., Cameron, M. P., and Huong, V. V. (2014a). Farmland Loss and Livelihood Outcomes: a Microeconometric Analysis of Household Surveys in Vietnam. Journal of the Asia Pacific Economy, 19(3), 423-444.

[32] Tran, Q. T., Lim, S., Cameron, M., and Van Huong, V. (2014b). Farmland Loss, Nonfarm Diversification and Inequality among Households in Hanoi's Peri-urban areas, Vietnam. International Development Planning Review, 36(3), 357-379.

[33] Wells-Dang, A. (2013). Promoting Land Rights in Vietnam: A Multi-sector Advocacy Coalition Approach. In Annual World Bank Conference on Land and Poverty. Washington $D C$.

[34] World Bank. (2009). Country Social Analysis: Ethnicity and Development in Vietnam. Washington DC.

[35] World Bank. (2011). Voluntary Land Conversion in Vietnam: The Conceptual Approach, Land Valuation and Grievance Redress Mechanism. World Bank, Hanoi. World Bank. https://openknowledge.worldbank.org/handle/10986/26886

[36] World Bank. (2014). Introduction to Poverty Analysis. Washington, DC: World Bank Group. http://documents.worldbank.org/curated/en/775871468331250546/Introductionto-poverty-analysis

[37] Xu, Y., Tang, B. S., and Chan, E. H. (2011). State-led Land Requisition and Transformation of Rural Villages in Transitional China. Habitat International, 35(1), 57-65.

[38] Yusuf, S. A. (2008). Social Capital and Household Welfare in Kwara State, Nigeria. Journal of Human Ecology, 23(3), 219-229. 


\section{Appendix A: Summary Statistics}

Table A1: Summary Statistics

All Households without Households with Differences Land Expropriated Land Expropriated (2) - (3)

$(1)$

\section{Panel A: Outcome Variables}

Monthly Food Expenditure

Income from Agriculture

Income from Wage/Salary

Fraction Having a Waged/Salaried Job

Income from Common Property Resource

Income from Self-Employment

Number of Days Spent in Agriculture Work Each Month

Number of Days Spent in Non-Agriculture Work Each Month

Market Value of Agricultural Capital
(2)
(4)

$\begin{array}{cc}558 & -17 \\ (435) & \\ 9,383 & 906 \\ (20,538) & \\ 9,757 & -1,697 \\ (14,718) & \\ 0.596 & 0.009 \\ (0.491) & \\ 428 & 46 \\ (2,410) & \\ 5,740 & 27 \\ (21,109) & \\ 22.956 & -1.273 \\ (24.036) & \\ 17.752 & 3.304 \\ (16.455) & \\ 1,344 & -285 \\ (11,234) & \end{array}$

0.364

$(0.252)$

4.069

(1.765)

0.760

$(0.427)$

56.677

(13.455)

0.754

(0.431)

0.154

$(0.361)$

0.100

(0.301)
$-0.364$

0.511

0.058

$-5.492$

$-0.045$

0.080

$-0.028$ with the Communist Party

(0.275)

$(0.259)$

3,315

Sample size

9,381

6,066

Notes: Monetary values are in thousands of VND and converted to the 2000 constant price. Household size is the total number of household members. Gender takes a value of 1 for female and 0 otherwise. Years of education are grades completed, top coded at 12 . 
Table A2: Impacts of Compulsory Acquisition on Household Income Share

\begin{tabular}{lcccc}
\hline & $\begin{array}{c}\text { Income Share } \\
\text { from } \\
\text { Agriculture } \\
(1)\end{array}$ & $\begin{array}{c}\text { Income Share } \\
\text { from } \\
\text { Salaried Jobs } \\
(2)\end{array}$ & $\begin{array}{c}\text { Income Share } \\
\text { from Common } \\
\text { Property Resource } \\
(3)\end{array}$ & $\begin{array}{c}\text { Income Share } \\
\text { from } \\
\text { Self Employment } \\
(4)\end{array}$ \\
\hline Fraction of Land Expropriated & $-0.135^{* * *}$ & $0.089^{* * *}$ & 0.018 & 0.019 \\
& $(0.029)$ & $(0.033)$ & $(0.011)$ & $(0.024)$ \\
Sample Size & 9,206 & 9,205 & 9,205 & 9,206 \\
\hline \hline
\end{tabular}

Notes: Robust standard errors are clustered at household level. ${ }^{*} p<0.1,{ }^{* *} p<0.05,{ }^{* * *} p<0.01$. All Controls include (i) household characteristics such as gender, age, age squared, ethnicity, and education of household head, household size, demographic composition of household (proportion of young children and elderly disaggregated by gender), household total land area (in $\log$ ), and whether any household member is affiliated with the Communist Party; (ii) household and year fixed effects, (iii) province-specific linear trend.

Figure A1: Fraction of Land Expropriated among Affected Households

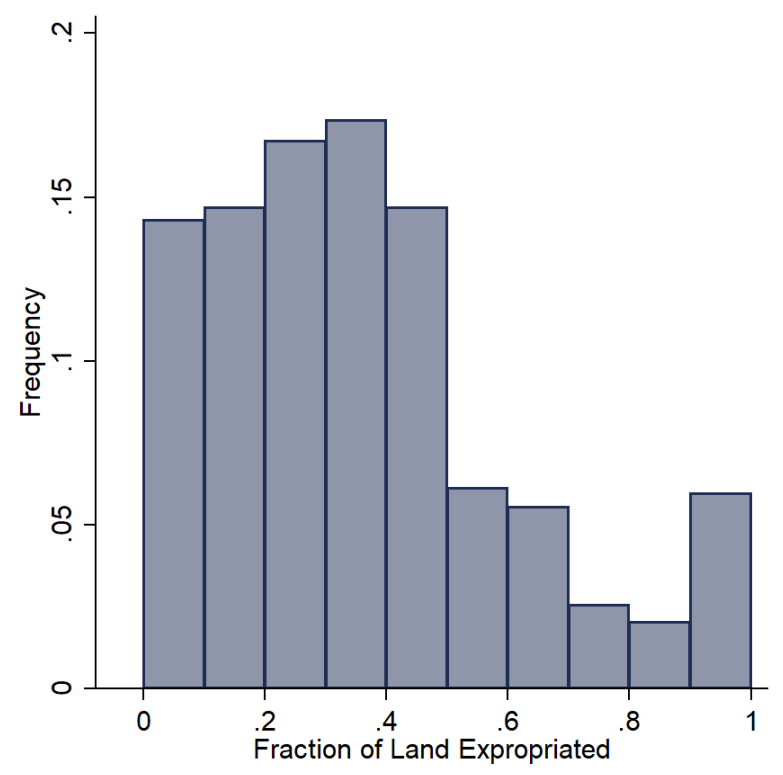




\section{Appendix B}

In this appendix, we compare our study with Tran et al. (2014a, 2014b) that also study the case of Vietnam with different sample and methodology. We see our paper as an improvement and complement to Tran et al. (2014a, 2014b). First, in terms of data, Tran et al. (2014a, 2014b) cover 1 peri-urban district in Hanoi (the capital city) over 2 years. The authors use cross-sectional data with a sample size of fewer than 500 observations. Our paper covers 134 districts across the country for over 8 years. We employ the household panel data with a sample size of over 9,000 observations. Thus, we improve Tran et al. (2014a, 2014b) by having a more representative sample and more efficient estimates.

Second, our paper differs from Tran et al. (2014a, 2014b) in the empirical methodology. Tran et al. (2014a, 2014b) use the multinomial logit model and do not deal with the endogeneity of farmland expropriation. We adopt the household fixed effects model to deal with the endogeneity of farmland expropriation. We also provide a series of placebo tests to support the internal validity of our estimates.

Third, there are also differences in the main explanatory variable. Tran et al. (2014a, 2014b) only look at the extensive margin of expropriation, i.e., whether household lost their land in a given year (1 year or 2 years ago). However, our explanatory variables capture both the extensive and intensive margins of compulsory acquisition. Our variables further allow us to explore the effects over time.

We proceed to compare the findings. Regarding household income, Tran et al. (2014a) does not detect any effect of expropriation on household income. However, Tran et al. (2014b) uncovers a decrease in the share of agricultural income and an increase in the share of wages/salaries, which is mainly because expropriated households were able to switch from agricultural to non-agricultural sectors. The use of income share does not correctly reflect the increase or decrease in each activity. For example, the increase in wages/salaries share could simply result from the reduction in agricultural earnings without the actual increase in earnings from waged work. On the other hand, we directly examine earnings (not the share) from various revenue-generating activities (e.g. agriculture, salaried jobs, self-employment). In this sense, our income measures are more meaningful and provide direct earnings comparison in each activity. We find that compulsory acquisition reduces household income from agriculture. The effect on household income from salaried jobs is positive but 
falls short of statistical significance.

As for the results on household expenditure and occupation choice, Tran et al. (2014a) find that the positive effects on household expenditure diminish after 2 years. It also takes expropriated households 2 years to switch to non-agricultural occupations. However, with larger sample size and a longer time period, our paper reveals that expropriated households reduce their working time in agriculture but are unable to transition into non-agricultural jobs. While diminishing over time, the negative effects of compulsory acquisition on household welfare may take up to 10 years to evaporate. It is possible that land-losing households in Tran et al. (2014a) live in a peri-urban area of the capital city, therefore, they could have better non-farm employment opportunities. Nevertheless, land-losing households in our context reside in rural areas of 12 Vietnamese provinces, hence, they may have relatively limited access to the non-agricultural labor market. 